\title{
Gp100:280-288 Peptide Vaccine
}

National Cancer Institute

\section{Source}

National Cancer Institute. gp100:280-288 Peptide Vaccine. NCI Thesaurus. Code C2767.

A vaccine consisting of the amino acids 280 through 288 of the melanoma antigen

glycoprotein 100 (gp100) with potential antineoplastic activity. Vaccination with gp100:280-288 peptide may stimulate the host immune system to mount a cytotoxic $T$ lymphocyte $(C T L)$ response ag ainst tumor cells positive for the gp100 antigen, resulting in decreased tumor growth. ( $\mathrm{NClO4})$ 